\title{
Market Access, Soil Fertility, and Income in East Africa
}

By

Takashi Yamano

and

Yoko Kijima

December 2010
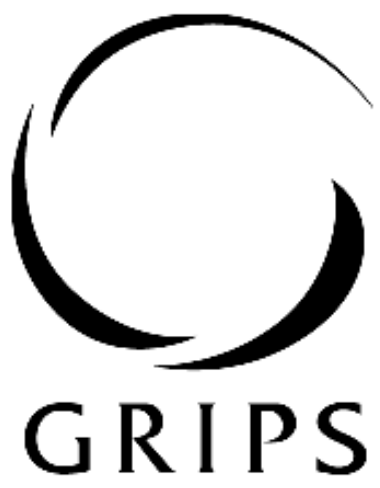

National Graduate institute FOR POLICY STUDIES

National Graduate Institute for Policy Studies

7-22-1 Roppongi, Minato-ku,

Tokyo, Japan 106-8677 


\title{
Market Access, Soil Fertility, and Income in East Africa
}

\author{
Takashi Yamano ${ }^{1}$ and Yoko Kijima ${ }^{2}$
}

\begin{abstract}
We identify the major factors affecting farm and nonfarm income by using panel data in Ethiopia, Kenya, and Uganda. We supplement the panel data with household-level soil fertility data and road distance data to the nearest urban center. The proportion of the loose surface roads, instead of tarmac roads, has a clear negative association with crop income, livestock income, and per capita income in both Kenya and Uganda. We also find that soil fertility has a clear positive association with crop and livestock incomes in Kenya, but not in Uganda and Ethiopia. In Kenya, farmers produce not only cereal crops but also high value crops and engage in dairy and other livestock production if the fertility of the soil is good.
\end{abstract}

Key words: Soil Fertility, Market Access, Poverty, Road Infrastructure, East Africa

${ }^{1}$ Foundation for Advanced Studies on International Development, National Graduate Institute for Policy Studies, Japan

${ }^{2}$ Tsukuba University, Japan

Correspondent author, Takashi Yamano, Foundation for Advanced Studies on International Development, National Graduate Institute for Policy Studies, 7-22-1, Roppongi, Minato-ku, Tokyo, 106-8677, Japan yamanota@grips.ac.jp 


\section{Introduction}

In the previous case studies in this book, we have separately examined the causes and consequences of the adoptions of various technologies and inputs, while controlling for market access and soil fertility. The main motivation of these case studies as explained in Chapter 1, is that poverty is a consequence of the low endowment of assets and the low returns to such assets (Baulch and Hoddinott, 2000; Barrett, 2005; Carter and Barrett, 2006). The returns to the productive assets depend critically on technology and market access. For instance, improved seed varieties, combined with modern inputs, can increase crop yields dramatically, although the adoption of such technologies has been slow in Sub-Saharan Africa (SSA) compared to the rapid adoption of such technology in Asian countries during the Green Revolution period. Poor market access, in addition, increases input costs and reduces the selling prices of farm products and, hence, discourages farmers from participating in markets (de Janvry et al., 1991).

Market access and soil fertility are generally poor in African countries, as we discuss in Chapter 1. Rural roads are generally inadequate in terms of both coverage and quality, resulting in high transportation costs in Africa (Calderón and Servén, 2008). The high transportation costs increase inorganic fertilizer prices, discourage farmers from producing perishable and high-value crops, and hence prevent farmers from increasing farm income. Regarding assets, land is one of the most important assets because most rural households rely heavily on farm income in Africa. The quality of the land, however, is considered to be deteriorating because of continuous cultivation with 
little external fertilizer application and inadequate land management (Smaling et al., 1997; Nkonya et al., 2004; Nkonya et al., 2008). In the previous chapters in this book, we have not examined how these factors are associated with the total income and welfare of the rural households.

In this chapter, therefore, we identify the associations of soil fertility, agricultural technology, and market access with incomes from three sources, i.e., crop, livestock, and non-farm income in Ethiopia, Kenya, and Uganda. We use panel data in each of the three countries, interviewed twice in the period between 2003 and 2007, and estimate determinants of crop, livestock, and non-farm incomes, in addition to total per capita income. The results indicate that the proportion of murram or dirt roads, instead of tarmac roads, has strong negative associations with the crop and livestock incomes in Kenya and Uganda. This suggests that converting loose-surface roads to tarmac roads would increase the total per capita income in these two countries. In Ethiopia, we find an opposite result, which we believe is a result of program placements of a large-scale fertilizer credit program in the country.

The outline of this chapter is as follows: the next section discusses the conceptual framework on how soil fertility and market access affect rural poverty. Section 12.3 introduces the panel data used in this chapter. We explain the estimation models and how we measure the soil fertility and the distance to the nearest urban center in Section 12.4. The estimation results are provided in Section 12.5, which is followed by the conclusions in Section 12.6.

\section{Conceptual Framework}


Land degradation decreases the returns to land in a number of ways. We found that the soil carbon content, which is used as an index for soil fertility, has a strong positive association with maize yields in Kenya and Uganda (Chapter 7) and with banana yields in Uganda (Chapter 8). Also the reduction in soil fertility decreases the application of inorganic fertilizer (Chapter7), presumably because it reduces the returns to external fertilizer (Marenya and Barrett, 2009). Because of these impacts, we expect that farm households with poor soils have lower crop income than farm households with fertile soils, after controlling for the land size and other factors.

A possible means to compensate for the low crop income is to increase the income from other sources. There are two major non-crop income sources in the context of East Africa: livestock and nonfarm income. Livestock income includes income from sales of livestock and livestock products. In areas with low soil fertility and abundant land, the land could be used for grazing animals. In East Africa, grazing animals, especially local cattle, is popular in some remote regions, where rural households rely more on livestock income than in other regions. In areas with unfavorable agro-ecological conditions to agricultural production, both the crop and livestock activities may have low returns. Such low farm income is considered as a "push factor" that forces rural households into seeking nonfarm activities (Reardon et al., 2007; Haggblade et al., 2007). In Asian countries, many farm households in unfavorable agricultural areas have escaped from poverty by increasing their nonfarm income over time (Otsuka and Yamano, 2006; Otsuka et al., 2008). ${ }^{1}$ In the three countries studied in

\footnotetext{
${ }^{1}$ For instance, over a 17-year period from 1987 to 2004 in Thailand, the increase in the nonfarm income share in the Northeast region, where the agricultural potential is low, was much
} 
this chapter, the non-farm sectors are at different development. For instance, Matsumoto et al. (2006) show that the share of nonfarm income is 45 percent in Kenya, 30 percent in Uganda, and 5 percent in Ethiopia.

Regarding the relationship between market access and household welfare, there is a growing body of literature (Jacoby, 2000; Minot, 2007; Stifel and Minten, 2008). Jacoby (2000), for instance, finds a negative relationship between the value of farmland and the community level median traveling time to the nearest market centre or agricultural cooperative in Nepal. A more recent study by Stifel and Minten (2008) find that the crop yields of the three major crops in Madagascar, i.e. rice, maize, and cassava, are lower in isolated areas than in non-isolated areas. Although Jacoby (2000) and Stifel and Minten (2008) control for soil fertility in their analyses, their measurements of soil fertility are based on categorical classifications of soil fertility.

In this chapter, we extend these analyses in several ways. First, we use much more detailed soil-fertility-related variables than in their studies. Second, both studies use the traveling time and cost variables at the community level to avoid measurement errors and endogeneity problems associated with the traveling time and costs. The endogeneity problem arises when households with better welfare or high agricultural productivity invest in better means of transportation. Our distance variable, however, is based on the geographical information system (GIS) coordinates of the sampled households. Thus, measurement errors do not depend on how the respondents estimate the traveling time, and the endogeneity problems, a point of concern in the previous higher than that in the Central region, where the agricultural potential is high (Cherdchuchai and Otsuka, 2006). The authors conclude that the large decline in the poverty incidence in the Northeast region can be attributed primarily to the increased nonfarm income. 
studies, are not of concern because the GIS measured distance is not subject to change by household behavior. Lastly, while the previous studies examined impacts of markets on land values or crop yields, our analysis extends this to broader impacts on household income.

\section{Data and Descriptive Analyses}

\subsection{Data}

Among the three countries, Kenyan farmers have a higher income than Ugandan and Ethiopian households (Table 1). In Kenya, the average per capita income (all values are calculated using 2005/06 prices) was USD 392 in 2004 and USD 333 in 2007. ${ }^{2}$ The average per capita income in Uganda is less than half of that in Kenya. Furthermore, the average per capita income in Ethiopia is much lower than in Uganda. As a result, the average per capita income in Ethiopia is less than one third of that in Kenya. Thus, although our sample households are poor by international standards, the level of the poverty differs considerably among our sample households across the three countries.

In Table 1, we also present the proportions of our sample households whose soil fertility data are available. Along with the first waves of the panel surveys in the

\footnotetext{
${ }^{2}$ We divide the total household income into crop income, livestock income, and nonfarm income. We calculate crop income by valuing all production and then subtracting the paid-out costs, which include the costs of seeds, fertilizer, hired labor, and oxen rental, from the total value production. In the case of livestock income, we included revenue from live sales plus production value of livestock products and then subtracted the paid out costs, which include purchased feeds, expenditure on artificial insemination services, bull services, and animal health care services, out of the revenue which consists of sales of animals and livestock products, such as milk and eggs. To calculate the nonfarm income, we sum the monthly revenues for the past 12 months and subtract the monthly costs out of the total annual revenue and salaries from jobs that provide regular monthly salaries as well as wage earnings from seasonal jobs.
} 
three countries, we conducted soil sampling and measured a number of soil characteristics, as described in Chapter 1. We collected soil samples from the largest maize plot if the household cultivated maize and, if the household did not cultivate maize, we collected soils from the largest plot of non-maize cereal crops during the first cropping season of the first survey year. When the sampled households produced no cereal crops, we did not collect any soil samples. Moreover, some soil samples were lost or spoiled before being analyzed at the laboratory. As a result, the soil fertility data are only available for about 74 percent of samples households in the three countries studied in this chapter. The average soil carbon content is 2.4 in Kenya, 2.3 in Uganda, and 2.4 in Ethiopia. The Ethiopian samples have a smaller variation than the samples from the other two countries: the standard deviation is 1.1 in Ethiopia but is 1.5 in both Kenya and Uganda.

\subsection{Soil fertility and income}

To analyze the relationship between the soil fertility and the household income, we divide the sample households into four groups according to the soil carbon content in Table 2. Note that because we have the soil fertility data only for the sub-sample households, we only present the results among the sub-sample in this table. The table suggests that as soil fertility improves, per capita income increases in Kenya, but such a relationship cannot be found in Uganda. In Ethiopia, the relationship between the soil fertility and per capita income is opposite from what we find for Kenya. The unexpected 
relationship in Ethiopia is probably due to a large scale fertilizer credit program, which distributes the fertilizer credit to farmers regardless of the market access and soil fertility as shown in Chapter 4 in this book. Regarding the composition of the income sources, we find a clear pattern in Kenya and Uganda. The share of crop and livestock incomes increases as the soil fertility improves, in contrast to the share of non-farm income. The results are consistent with the "push factor" explanation that combination of poor soil fertility and low farm income pushed people into non-farm activities to compensate for the low farm income.

The findings in Table 2 are informative, but the soil fertility could be correlated with other factors, especially with geographical factors, which may influence the welfare of the rural households. The level of soil fertility and the degree of market access, for instance, would be negatively correlated if cities and towns are formed around fertile land, as predicted by economic geography (Fujita et al., 2001). Thus, it is not clear if it is the low soil fertility or the poor market access that contributes to the low crop income. Moreover, the relationship between soil fertility and income may be bi-directional in that higher income may enable households to invest more in soils. To isolate the association of the soil fertility on the crop and other household incomes from others factors, and to discern causality from association, we rely on regression analyses.

\section{Estimation Models and Variables}

\subsection{Estimation models}

We estimate the determinants of the crop, livestock, and nonfarm income with 
the Tobit model with the household random effects:

$$
\ln \left(Y_{i t}^{K}\right)=S_{i} \beta_{S}^{K}+M_{i} \beta_{M}^{K}+X_{i t} \beta_{X}^{K}+e_{i t}^{K},
$$

where $Y_{i t}^{K}$ is the log of the income from source $K ; S_{i}$ is a set of soil characteristics of household $i ; M_{i}$ is a set of market access variables of household $i$; and $X_{i t}$ is a set of basic household characteristics of household $i$ at time $t$. We have three income sources: crop income $(K=1)$, livestock income $(K=2)$, and non-farm income $(K=3)$. In addition, we also estimate the determinants per capita of total income $(K=4)$. Because we have panel data at the household level and have some observations with zero income for some income sources, we estimate the model with the household Random Effects (RE) Tobit model. Because it is difficult to collect information on family labor inputs, we did not collect such information in our surveys. Thus, income is estimated by subtracting the paid-out costs from the value of production. Accordingly, the crop, livestock, and nonfarm incomes should be considered as the sum of the returns to the land, family labor, and unmeasured ability of the family members.

There are two major limitations with the estimation models. The first limitation is that we have at most one soil sample per household. Because of this limitation, we assume that the soil fertility is constant over time and across plots that belong to each sample household in order to use all the observations in our panel data. Because the carbon content, our main soil fertility index, is stable over time as we mentioned earlier, this assumption may be acceptable regarding the time dimension. It could be, however, a strong assumption to apply across plots within households, especially when the plots are scattered. Tittonell et al. (2005), for instance, find that plots which are located close 
to homesteads are more fertile than remote plots by using soil samples of 60 households in western Kenya. Thus, using the soil fertility data from one plot may generate biased estimators.

Despite these limitations, however, we have two reasons for maintaining our assumption. First, the same study, Tittonell et al. (2005), finds a relatively smaller variation in soil carbon across plots within households than in other soil nutrient variables, such as extractable $\mathrm{P}$ and $\mathrm{K}$. The study finds a larger variation in soil carbon across communities than within households. Thus, regarding the soil carbon content, which we use as the main soil fertility indicator in this chapter, the potential bias problem may not be as serious as it would have been had we chosen other soil nutrient variables. Second, we use a large number of soil samples covering a wide geographical area in each country. Thus, there is significant variation in the soil carbon content across geographical areas which helps to identify relationships between the soil fertility and the incomes.

The second major limitation of our estimation models is that, in addition to the soil fertility variables, the distance to roads and markets variables are also observed only once in our panel data. Moreover, these soil fertility and market access variables could be correlated with some omitted variables, such as farmers' ability. For instance, highly skilled or wealthy farmers might have invested in their soil fertility over time or have purchased land near roads in the past. If we had multiple observations, with sufficient variations of these variables over time, we could use models to control for unobserved household fixed effects and identify causal impacts. Without such multiple observations 
of the variables, we are unable to eliminate any potential biases created by omitted variables to identify causal impacts. Thus, in this study, we consider the results as observed associations between the independent variables and the outcome variables, instead of causal relationships between them.

\subsection{Variables}

For the soil variables, $S_{i}$, in the estimation models, we use the soil carbon content and its squared term, the $\mathrm{pH}$ and its squared term, and the ratio of sandy soil, as opposed to clay or loam soil. ${ }^{3}$ We use the squared terms of the soil carbon and $\mathrm{pH}$ because we may find non-liner relationships between the outcome variables and the soil variables. Since the soil variables are available for just the sub-samples, we could estimate the models with the sub-samples only. This method, however, may create selection biases because the sub-samples with the soil fertility data are not selected randomly. To account for this, we replace all the soil related variables with zero values and include an additional dummy variable for those households without soil data. To assure that our approach provides robust estimates, we estimate the same model for the entire sample and the sub-sample of households with soil data.

As mentioned earlier, to measure market access, $M_{i}$, we use the distance to the nearest urban center (above 100,000 inhabitants) on the three road types: dirt (or dry-weather only roads), loose-surface (all-weather roads), and tarmac road (all-weather roads, bound surface). Researchers at the International Livestock Research Institute,

\footnotetext{
${ }^{3}$ In this chapter, we do not present the results on the soil-fertility-related variables, other than the soil carbon content, to save space, although we include them in the regression models. The results on the other soil-fertility-related variables are not significant for the most part.
} 
using a method employed by Baltenweck and Staal (2007), provided us the data in Kenya, Uganda, and Ethiopia. They used the GIS coordinates of the sampled households and the most recent digitized road maps of the three countries.

The household characteristics include human capital and asset variables. First, the human capital variables include the number of male and female adult members, 15 years old or older, in the household and the maximum education levels of the male and female adult members. We use a dummy variable for female headed households. Among household assets, we include the own land size in hectares and the total value of the household farm equipment, furniture, transportation means, communication devices, and other household assets; and the livestock value, which is the sum of the replacement values of cattle, goats, sheep, chickens, and pigs. Because the size and fertility of the land are separately included in the model, we do not include the value of land as a household asset.

\section{Results}

\subsection{Kenya}

According to the estimation results in Table 3, market access affects both crop and livestock incomes in Kenya. We find that per capita crop income and the per capita livestock income decline USD 8.7 and USD 5.4, respectively, among households who have such incomes, for every $10 \mathrm{~km}$ from the nearest urban center. In addition, both incomes decline further if the proportion of loose surface roads, instead of tarmac roads, increases. If all the roads linking a household to an urban center were loose surface 
roads, instead of tarmac roads, the crop income would decrease by USD 42 and the livestock income would decrease by USD 33. Regarding non-farm income, we do not find any significant associations between market access and the non-farm income. While good market access enables rural households to engage in non-farm activities, poor market access pushes rural households to seek non-farm income by migrating to urban centers. These opposing effects cancel each other out and make it difficult for us to find a clear impact toward one direction.

Soil fertility, measured in the carbon content, has a positive and significant impact on both crop and livestock incomes, while it does not have any significant impacts on non-farm income. In the crop income regression, the positive effect suggests that good soil enables farmers to choose crops that have high returns in Kenya, and to obtain high yields from crops, as shown by Chapter 7 . Because the squared term of the carbon has a negative coefficient on both crop and livestock incomes, the relationship between soil fertility and each income source has a peak. A quick calculation shows that the crop income model has a peak where the soil carbon content is about 10. Since the carbon content value at the 90th percentile is 9.2 in Kenya, we can safely state that the crop income increases as the carbon content increases within much of the observable range of the data. The peak carbon content for livestock income is at 6.6 and there exist some households whose soil fertility is beyond 6.6. It may be that those who have fertile soils focus on crop production, instead of livestock production, because their crop production has large returns due to the high soil fertility.

Regarding household characteristics, we find that the crop income increases as 
the size of land owned increases in Kenya. This is what is expected because the dependent variable is the "total" crop income per capita. When we estimate the same model for the crop income per ha, we find that the land size has a negative relationship with the crop income per ha. In fact, we find the same pattern, i.e., a positive coefficient on the total crop income and a negative coefficient on the crop income per ha, in all three countries. This suggests that smaller farmers have a high productivity per land in these countries. Although some farmers still have large lands which are not cultivated intensively in these countries, the number of such farmers is decreasing. Compared with such farmers, small land holders intensify their production by using relatively abundant family labor. This could be why we find higher productivity among small land holders.

Next we find that the number of improved cattle has a positive coefficient on all income sources. Depending on the specific dependent variable, the results may be more indicative of an association rather than a causal relationship. For instance, the positive coefficient of this variable in the non-farm income regression model suggests that the number of improved cattle is a proxy for household wealth, which is positively correlated with the non-farm income. On the crop income, however, we believe that the positive coefficient of the number of improved cattle captures, at least partly, a complementary effect in dairy-crop integration where farmers use cattle manure, obtained from improved cattle, as organic fertilizer, as studied in Chapter 8 in this book. This may be supported by the absence of the significant effect of local cattle ownership on crop income, as improved cattle kept in stalls provide more manure which is also more easily collected as compared to local cattle. 
In Kenya, both men's and women's education have positive coefficients on non-farm income, and the magnitude of the women's coefficient is larger than the men's. Previous studies on non-farm income show that education is an important requirement to be engaged in such activities in both Asia and Africa (Otsuka et al., 2008; Matsumoto et al., 2006). We do not find significant coefficients of men's and women's education levels on the crop income. This suggests that there are few agricultural technologies that require high levels of education.

\subsection{Uganda}

Contrary to what we find in Kenya, crop income is higher in remote areas in Uganda (Table 4). This is understandable in Uganda where high value crops such as banana and coffee are produced in highland or mountainous areas which happen to located in the extreme east, west, and southwest of the country. Holding the distance to urban centers constant, however, we find that the crop income decreases significantly if the proportion of loose surface roads is higher instead of tarmac roads. If all the roads were loose surface roads, instead of tarmac roads, the crop income per capita would decrease by USD 97. Because banana can be spoiled easily on bumpy roads when they are transported on trucks, the proportion of loose-surface roads may have a negative impact on the price of banana. Thus, there is a potential gain that could be obtained by upgrading loose-surface roads to tarmac roads. On dirt roads, we do not find a significant coefficient, which may suggest that such roads are not used for transporting high value crops. 
In Uganda, we find that soil fertility does not have any significant coefficients on all three income sources. The soil samples are taken from plots where cereal crops are cultivated. As we mentioned earlier, banana is an important staple crop which tends to have high returns. Thus, the soil fertility data may not represent soil fertility where banana is cultivated, and this could be why we do not find significant coefficients for the soil fertility on the crop income.

Both the numbers of local and improved cattle increase the livestock income, suggesting the importance of the ownership of cattle in this country. Compared with the finding for Kenya, the size of the estimated coefficient of the number of improved cattle in Uganda is smaller. In Kenya, dairy farmers who own improved cattle are very successful in producing and selling large amounts of milk in a liberalized milk market, as shown in Chapter 5. In contrast, the Ugandan dairy sector is not as advanced as in Kenya. The smaller coefficient on the improved cattle on the livestock income in Uganda than in Kenya suggests a need for improvements in the dairy sector in Uganda. Another difference is that in Uganda, the number of improved cattle does not have a significant coefficient on the crop income, as we find in Kenya. This also suggests that the dairy-crop production system is not as well integrated as in Kenya, although there are some farmers who integrate them in Uganda, as shown in Chapter 8.

\subsection{Ethiopia}

In Ethiopia, crop income does not have clear relationships with either market access or soil fertility (Table 5). As Chapter 4 in this book shows, fertilizer credit is 
provided to farmers regardless of their agricultural potential, including market access and carbon content. Because the fertilizer credit program is a large-scale operation in Ethiopia, its politically determined distribution pattern may help explain why we do not find any relationships between the crop income and both the market access and the soil fertility in the country.

The numbers of local and improved cattle have positive coefficients on the livestock income. Moreover, as in Kenya, the improved cattle have a larger impact on livestock income than the local cattle, which suggests that the introduction of improved cattle is an important innovation. The number of improved cattle also has a positive coefficient on the crop income. Thus, in Ethiopia, we find evidence that the dairy-crop integration has a complementary effect. Because the soil fertility is very poor in some areas of Ethiopia, organic manure taken from improved cattle, which are easy to collect manure from, may be very effective in improving soil fertility in the country.

\subsection{Total Per Capita Income}

Regarding the market access, we find that the proportion of loose surface roads has large negative relationships with per capita income in Kenya and Uganda. These results indicate that farmers' income increases if the loose surface roads are converted to tarmac roads. In Ethiopia, the proportion of the loose surface roads has a positive correlation with per capita income. This is most likely due to the positive correlation between the proportion of loose surface roads and the crop income, found in Table 3 . Because farmers have a very low level of non-farm income in Ethiopia, the results on 
per capita income are similar to the ones for the crop income per capita.

We find no significant relationships between soil fertility and per capita income (Table 6). An earlier study by Yamano and Kijima (2010), who use the same Ugandan data set used in this chapter, suggests that households with poor soil fertility tend to earn more non-farm income than those households with better soils. As a result, they find that the total income has no relationship with the soil fertility. We think that the same explanation can be applied to the other two countries. Especially in Kenya, households have a high level of non-farm income (Matsumoto et al., 2006). Thus, it is possible for them to compensate the low farm income, due to poor soils, with the non-farm income. This also indicates that households with poor soil fertility do not find it worthwhile to invest in enriching their soils and prefer instead to seek returns through other means.

Men's education level has a strong positive correlation with per capita income both in Kenya and Uganda. This suggests that men are engaged more in non-farm activities than in farm activities in these countries, as we did not find similar results on the crop income in the previous tables. In Kenya, we also find a positive coefficient on women's education, and the size of the positive coefficient is larger than that on men's education. This suggests the importance of improving women's education levels for poverty reduction in Kenya. Finally, we find that both local and improved cattle ownership have positive relationships with per capita income. Although the causality is not clear, the results indicate the importance of cattle ownership in the three countries.

\section{Conclusion}


In this chapter, we explored income levels and their composition in three East African countries and then analyzed the degree to which they are related to soil fertility, agricultural technology, and market access. First, a key point is that agriculture is still vitally important to overall household income throughout the region. This is supported by the high proportion of income from crop and livestock and also the importance of land size to overall household income. The analytical results indicate that the proportion of the loose surface roads, instead of tarmac roads, has a clear negative association with crop income, livestock income, and per capita income in both Kenya and Uganda, while controlling for the total distance to the nearest urban center. Transportation costs per unit distance on loose surface roads are higher than those on tarmac roads in general. During rainy seasons especially, surface roads can be impassable, which increases transportation costs significantly and leads to the spoilage of relatively perishable crops such as banana. The results, therefore, indicate the importance of road quality, in addition to the distance to urban centers.

We find that soil fertility has a clear association with crop and livestock incomes in Kenya, but not in Uganda and Ethiopia. In Kenya, farmers produce not only cereal crops but also produce high value crops and engage in dairy and other livestock production if the fertility of the soil is good. Good soil fertility also increases land productivity as shown in the case of maize in Chapter 7 of this book. In Uganda and Ethiopia, soil fertility is lower than in Kenya on average, but the difference is small, and there are many farmers with very good soil in both countries. What is necessary in these countries are technologies and crops that can take advantage of the good soil and market 
opportunities. Without such technologies and market opportunities, investments in soil fertility will have only low returns. 


\section{References}

Baltenweck, I. \& Staal, S. (2007). Beyond One-Size-Fits-All: Differentiating Market Access Measures for Commodity Systems in the Kenyan Highlands. Journal of Agricultural Economics, 58, 536-548.

Barrett, C. B. (2005). Rural Poverty Dynamics: Development Policy Implications. Agricultural Economics, 32, 45-60.

Baulch, B. \& Hoddinott, J. (2000). Economic Mobility and Poverty Dynamics in Developing Countries, London: Frank Cass.

Calderón, C. \& Servén, L. (2008). Infrastructure and Economic Development in Sub-Saharan Africa. Policy Research Working Paper 4712, World Bank, Washington D.C.

Carter, M. \& Barrett, C. B. (2006). The Economics of Poverty Traps and Persistent Poverty: An Asset-Based Approach. Journal of Development Studies, 42, 178-199.

Cherdchuchai, S. \& Otsuka, K. (2006). Rural Income Dynamics and Poverty Reduction in Thai Villages from 1987 to 2004. Agricultural Economics, 35, 409-423.

de Janvry, A., Fafchamps, M. \& Sadoulet, E. (1991). Peasant Household Behavior with Missing Markets: Some Paradoxes Explained. Economic Journal, 101, 1400-1417.

FAO (2008). FAOSTAT at http://faostat.fao.org/default.aspx

Fujita, M., Krugman, P. \& Venables, A. J. (2001). The Spatial Economy: Cities, Regions, and International Trade, Cambridge, Massachusetts: MIT Press.

Haggblade, S., Hazell, P. B. R. \& Reardon, T. (2007). Transforming the Ruralnonfarm Economy. Baltimore: Johns Hopkins University Press.

Jacoby, H. G. (2000). Access to Markets and the Benefits of Rural Roads. Economic Journal, 110, 713-737.

Marenya, P. P. \& Barrett, C. B. (2009). State-Conditional Fertilizer Yield Response on Western Kenyan Farms. American Journal of Agricultural Economics, 91, 991-1006.

Matsumoto, T., Kijima, Y. \& Yamano, T. (2006). The Role of Local Nonfarm Activities and Migration in Reducing Poverty: Evidence from Ethiopia, Kenya, and Uganda. Agricultural Economics, 35, 449-458.

Minot, N. (2007). Are Poor, Remote Areas Left Behind in Agricultural Development: The Case of Tanzania. Journal of African Economies, 17, 239-276.

Nkonya, E., Pender, J., Kaizzi, C., Kato, E., Mugarura, S., Ssali, H. \& Muwonge, J. (2008). Linkages Between Land Management, Land Degradation and Poverty in Sub-Saharan Africa: The Case of Uganda," IFPRI Research Report No. 159, Washington, DC: International Food Policy Research Institute.

Nkonya, E., Pender, J., Jagger, P., Sserunkuuma, D. Kaizzi, C. K. \& Ssali, H. (2004). Strategies for Sustainable Land Management and Poverty Reduction in Uganda. Research Report No. 133, Washington, DC: International Food Policy Research Institute.

Otsuka, K., Estudillo, J. P. \& Sawada, Y. (2008). Rural Poverty and Income Dynamics in Asia and Africa. London, UK: Routledge.

Otsuka, K. \& Yamano, T. (2006). Introduction to the Special Issue on the Role of Nonfarm Income in Poverty Reduction: Evidence from Asia and East Africa. Agricultural Economics, 35, 393-397. 
Reardon, T., Berdegue, J., Barrett, C.B. \& Stamoulis, K. (2007). Household Income Diversification into Rural Nonfarm Activities. In S. Haggblade, P. B. R. Hazell \& T. Reardon (Eds.), Transforming the Rural Nonfarm Economy, Baltimore: The Johns Hopkins University Press.

Smaling, E. M. A., Nandwa, S. M. \& Janssen, B. H. (1997). Soil Fertility in Africa is at Stake. In R. J. Buresh, P. A. Sanchez \& F. Calhoun (Eds.), Replenishing Soil Fertility in Africa, Madison, WI: Soil Science Society of America.

Stifel, D. \& Minten, B. (2008). Isolation and Agricultural Productivity. Agricultural Economics, 39, 1-15.

Tittonell, P., Vanlauwe, B. Leffelaar, P. A., Sheperd, K. D. \& Giller, K. E. (2005). Exploring Diversity in Soil Fertility Management of Smallholder Farms in Western Kenya II. Within-farm Variability in Resource Allocation, Nutrient Flows and Soil Fertility Status. Agriculture, Ecosystems and Environment, 110, 166-184.

Yamano, T. \& Kijima, Y. (2010). The Associations of Soil Fertility and Market Access with Household Income: Evidence from Rural Uganda. Food Policy, 35, 51-59. 
Table 1. Size of Sample Households and Per Capita Income

\begin{tabular}{|c|c|c|c|c|}
\hline \multirow{3}{*}{ Region $^{1}$} & \multirow{2}{*}{$\begin{array}{l}\text { Number of } \\
\text { Households }\end{array}$} & \multicolumn{2}{|c|}{$\begin{array}{c}\text { Per Capita Income } \\
\text { (at 2005/6 Price Level) }\end{array}$} & \multirow{2}{*}{$\begin{array}{l}\% \text { of Households } \\
\text { with Soil Data }\end{array}$} \\
\hline & & $2003 / 4$ & $2005 / 6$ & \\
\hline & (A) & (B) & (C) & (D) \\
\hline & Number & \multicolumn{2}{|c|}{ USD } & $\%$ \\
\hline Kenya & 672 & 392.2 & 333.2 & 75.5 \\
\hline Uganda & 894 & 132.4 & 169.3 & 63.1 \\
\hline Ethiopia & 408 & 84.3 & 102.8 & 95.2 \\
\hline
\end{tabular}


Table 2. Household Crop Income and Fertilizer Use by the SOM Quartile among Soil Sub-sample

\begin{tabular}{|c|c|c|c|c|c|}
\hline & \multirow[b]{2}{*}{ All } & \multicolumn{4}{|c|}{ Soil Carbon Quartile } \\
\hline & & $\begin{array}{c}\text { Q1 } \\
\text { Poor Soil }\end{array}$ & Q2 & Q3 & $\begin{array}{c}\text { Q4 } \\
\text { Good } \\
\text { Soil } \\
\end{array}$ \\
\hline & (A) & (B) & (C) & (D) & (E) \\
\hline \multicolumn{6}{|l|}{ Kenya } \\
\hline Per Capita Income ${ }^{a}$ & 367.0 & 300.2 & 341.4 & 382.2 & 447.5 \\
\hline$\%$ Crop Income ${ }^{a}$ & 35.8 & 34.2 & 35.5 & 34.2 & 39.4 \\
\hline$\%$ Livestock Income ${ }^{a}$ & 24.2 & 22.2 & 23.0 & 23.7 & 28.0 \\
\hline$\%$ Nonfarm Income ${ }^{a}$ & 41.5 & 46.3 & 43.2 & 42.8 & 33.5 \\
\hline \multicolumn{6}{|l|}{ Uganda } \\
\hline Per Capita Income ${ }^{a}$ & 153.9 & 158.2 & 149.8 & 160.1 & 147.6 \\
\hline$\%$ Crop Income ${ }^{a}$ & 64.0 & 58.1 & 66.8 & 66.1 & 65.2 \\
\hline$\%$ Livestock Income ${ }^{a}$ & 12.7 & 11.0 & 12.6 & 14.0 & 13.3 \\
\hline$\%$ Nonfarm Income ${ }^{a}$ & 29.2 & 35.3 & 28.0 & 28.2 & 25.3 \\
\hline \multicolumn{6}{|l|}{ Ethiopia } \\
\hline Per Capita Income ${ }^{a}$ & 93.7 & 125.4 & 100.7 & 76.1 & 79.4 \\
\hline$\%$ Crop Income ${ }^{a}$ & 52.5 & 57.8 & 50.9 & 51.5 & 50.8 \\
\hline$\%$ Livestock Income ${ }^{a}$ & 34.0 & 28.7 & 33.6 & 34.8 & 37.8 \\
\hline$\%$ Nonfarm Income ${ }^{a}$ & 11.6 & 10.7 & 11.4 & 13.6 & 10.5 \\
\hline
\end{tabular}

Note: numbers are from the Soil Sub-Samples.

${ }^{a}$ Calculated from pooled data of 2003/4 and 2005/6; both values are adjusted to 2005/6 price level, USD. 
Table 3. Determinants of Crop, Livestock, and Non-farm Income in Kenya (Household Random Effects Model, USD)

\begin{tabular}{|c|c|c|c|}
\hline & $\begin{array}{l}\text { Per Capita } \\
\text { Crop Income }\end{array}$ & $\begin{array}{c}\text { Per Capita } \\
\text { Livestock } \\
\text { Income }\end{array}$ & $\begin{array}{l}\text { Per Capita } \\
\text { Nonfarm } \\
\text { Income }\end{array}$ \\
\hline & (A) & (B) & (C) \\
\hline \multicolumn{4}{|l|}{ Market Access to the Nearest Urban Center } \\
\hline \multirow[t]{2}{*}{ Total Distance (km) } & -0.874 & -0.537 & 0.648 \\
\hline & $(2.60)^{* * *}$ & $(1.77)^{*}$ & $(0.93)$ \\
\hline \multirow[t]{2}{*}{ Proportion of Loose Surface Road } & -42.38 & -32.61 & -30.78 \\
\hline & $(2.12)^{* *}$ & $(1.80)^{*}$ & $(0.74)$ \\
\hline \multirow[t]{2}{*}{ Proportion of Dirt road } & -6.723 & -39.97 & -16.05 \\
\hline & $(0.17)$ & $(1.09)$ & $(0.19)$ \\
\hline \multicolumn{4}{|l|}{ Soil Fertility } \\
\hline \multirow[t]{2}{*}{ Carbon } & 21.24 & 19.89 & -18.56 \\
\hline & $(2.10)^{* *}$ & $(2.18)^{* *}$ & $(0.89)$ \\
\hline \multirow[t]{2}{*}{ Carbon Squared } & -1.041 & -1.545 & 1.044 \\
\hline & $(1.35)$ & $(2.24)^{* *}$ & $(0.66)$ \\
\hline \multicolumn{4}{|l|}{ Household and Community Characteristics } \\
\hline \multirow[t]{2}{*}{ Land Size (ha) } & 18.50 & -3.050 & 0.217 \\
\hline & $(5.27)^{* * *}$ & $(0.96)$ & $(0.03)$ \\
\hline \multirow[t]{2}{*}{ Maximum Education Level of Male Adults } & 0.078 & 1.659 & 3.714 \\
\hline & $(0.08)$ & $(1.93)^{*}$ & $(2.00)^{* *}$ \\
\hline \multirow[t]{2}{*}{ Maximum Education Level of Female Adults } & 0.154 & -0.287 & 10.35 \\
\hline & $(0.17)$ & $(0.34)$ & $(5.62)^{* * *}$ \\
\hline \multirow[t]{2}{*}{ Female Headed Household Dummy } & -11.97 & -0.827 & -8.836 \\
\hline & $(1.29)$ & $(0.10)$ & $(0.47)$ \\
\hline \multirow[t]{2}{*}{ Number of Local Cattle Owned } & 0.072 & 9.211 & 5.422 \\
\hline & $(0.04)$ & $(5.75)^{* * *}$ & $(1.57)$ \\
\hline \multirow[t]{2}{*}{ Number of Improved Cattle Owned } & 5.404 & 21.01 & 7.063 \\
\hline & $(3.40)^{* * *}$ & $(14.3)^{* * *}$ & $(2.27)^{* *}$ \\
\hline \multirow[t]{2}{*}{ Constant } & -18.45 & 212.7 & -324.9 \\
\hline & $(0.06)$ & $(0.83)$ & $(0.55)$ \\
\hline
\end{tabular}

Note: * significant at $10 \%, * *$ significant at $5 \%, * * *$ significant at $1 \%$.

$\mathrm{pH}, \mathrm{pH}$ squared, numbers of male and female household members, numbers of sheep and goats, and a year dummy for the second round of the surveys are included but not presented in the table. 
Table 4. Determinants of Crop, Livestock, and Non-farm Income in Uganda (Household Random Effects Model, USD)

\begin{tabular}{|c|c|c|c|}
\hline & $\begin{array}{c}\text { Per Capita } \\
\text { Crop Income } \\
\text { (A) }\end{array}$ & $\begin{array}{c}\text { Per Capita } \\
\text { Livestock } \\
\text { Income }\end{array}$ & $\begin{array}{c}\text { Per Capita } \\
\text { Nonfarm } \\
\text { Income }\end{array}$ \\
\hline \multicolumn{4}{|l|}{ Market Access to the Nearest Urban Center } \\
\hline Total Distance $(\mathrm{km})$ & $\begin{array}{c}0.537 \\
(1.79)^{*}\end{array}$ & $\begin{array}{l}-0.147 \\
(1.40)\end{array}$ & $\begin{array}{l}-0.213 \\
(0.77)\end{array}$ \\
\hline Proportion of Loose Surface Road & $\begin{array}{c}-96.54 \\
(2.55)^{* *}\end{array}$ & $\begin{array}{l}-4.635 \\
(0.34)\end{array}$ & $\begin{array}{l}12.24 \\
(0.35)\end{array}$ \\
\hline Proportion of Dirt Road & $\begin{array}{l}-31.18 \\
(1.43)\end{array}$ & $\begin{array}{l}0.219 \\
(0.03)\end{array}$ & $\begin{array}{l}-0.941 \\
(0.05)\end{array}$ \\
\hline \multicolumn{4}{|l|}{ Soil Fertility } \\
\hline Carbon & $\begin{array}{l}10.190 \\
(1.20)\end{array}$ & $\begin{array}{l}0.663 \\
(0.21)\end{array}$ & $\begin{array}{l}-7.771 \\
(0.99)\end{array}$ \\
\hline Carbon Squared & $\begin{array}{l}-1.334 \\
(1.41)\end{array}$ & $\begin{array}{l}-0.343 \\
(0.92)\end{array}$ & $\begin{array}{l}0.710 \\
(0.83)\end{array}$ \\
\hline Household and Community Characteristics & & & \\
\hline Land Size (ha) & $\begin{array}{c}7.200 \\
(2.41)^{* *}\end{array}$ & $\begin{array}{l}0.652 \\
(0.69)\end{array}$ & $\begin{array}{l}-3.347 \\
(1.28)\end{array}$ \\
\hline Maximum Education Level of Male Adults & $\begin{array}{c}3.530 \\
(1.85)^{*}\end{array}$ & $\begin{array}{l}0.032 \\
(0.05)\end{array}$ & $\begin{array}{c}6.741 \\
(3.96)^{* * *}\end{array}$ \\
\hline Maximum Education Level of Female Adults & $\begin{array}{l}-1.935 \\
(0.92)\end{array}$ & $\begin{array}{c}1.600 \\
(2.26)^{* *}\end{array}$ & $\begin{array}{c}3.924 \\
(2.12)^{* *}\end{array}$ \\
\hline Female Headed Household Dummy & $\begin{array}{l}-12.88 \\
(0.65)\end{array}$ & $\begin{array}{l}-10.79 \\
(1.53)\end{array}$ & $\begin{array}{c}-46.44 \\
(2.49)^{* *}\end{array}$ \\
\hline Number of Local Cattle Owned & $\begin{array}{l}1.263 \\
(1.19)\end{array}$ & $\begin{array}{c}6.996 \\
(21.70)^{* * *}\end{array}$ & $\begin{array}{l}-1.854 \\
(1.94)^{*}\end{array}$ \\
\hline Number of Improved Cattle Owned & $\begin{array}{l}2.077 \\
(0.68)\end{array}$ & $\begin{array}{c}8.450 \\
(9.10)^{* * *}\end{array}$ & $\begin{array}{l}1.169 \\
(0.46)\end{array}$ \\
\hline Constant & $\begin{array}{c}-674.846 \\
(0.93)\end{array}$ & $\begin{array}{r}-5.534 \\
(0.02)\end{array}$ & $\begin{array}{l}-23.56 \\
(0.03)\end{array}$ \\
\hline
\end{tabular}

Note: * significant at $10 \%, * *$ significant at $5 \%, * * *$ significant at $1 \%$.

$\mathrm{pH}, \mathrm{pH}$ squared, numbers of male and female household members, numbers of sheep and goats, and a year dummy for the second round of the surveys are included but not presented in the table. 
Table 5. Determinants of Crop, Livestock, and Non-farm Income in Ethiopia (Household Random Effects Model, USD)

\begin{tabular}{|c|c|c|c|}
\hline & $\begin{array}{c}\text { Per Capita } \\
\text { Crop Income } \\
\text { (A) }\end{array}$ & $\begin{array}{c}\text { Per Capita } \\
\text { Livestock } \\
\text { Income }\end{array}$ & $\begin{array}{c}\text { Per Capita } \\
\text { Nonfarm } \\
\text { Income }\end{array}$ \\
\hline \multicolumn{4}{|l|}{ Market Access to the Nearest Urban Center } \\
\hline Total Distance $(\mathrm{km})$ & $\begin{array}{l}-0.016 \\
(0.19)\end{array}$ & $\begin{array}{l}0.041 \\
(0.72)\end{array}$ & $\begin{array}{l}-0.223 \\
(0.78)\end{array}$ \\
\hline Proportion of Loose Surface Road & $\begin{array}{l}23.610 \\
(1.60)\end{array}$ & $\begin{array}{l}-6.538 \\
(0.61)\end{array}$ & $\begin{array}{l}84.21 \\
(0.12)\end{array}$ \\
\hline $\begin{array}{l}\text { Proportion of Dirt Road } \\
\text { Soil Fertility }\end{array}$ & n.a. & n.a. & n.a. \\
\hline Carbon & $\begin{array}{c}-13.654 \\
(0.96)\end{array}$ & $\begin{array}{l}3.201 \\
(0.32)\end{array}$ & $\begin{array}{l}-37.81 \\
(1.47)\end{array}$ \\
\hline Carbon Squared & $\begin{array}{l}2.188 \\
(1.11)\end{array}$ & $\begin{array}{l}-0.020 \\
(0.01)\end{array}$ & $\begin{array}{l}5.352 \\
(1.53)\end{array}$ \\
\hline Household and Community Characteristics & & & \\
\hline Land Size (ha) & $\begin{array}{c}7.645 \\
(3.81)^{* *}\end{array}$ & $\begin{array}{l}0.158 \\
(0.11)\end{array}$ & $\begin{array}{l}2.855 \\
(0.87)\end{array}$ \\
\hline Maximum Education Level of Male Adults & $\begin{array}{l}-0.638 \\
(1.86)^{*}\end{array}$ & $\begin{array}{l}0.074 \\
(0.31)\end{array}$ & $\begin{array}{l}0.667 \\
(1.24)\end{array}$ \\
\hline Maximum Education Level of Female Adults & $\begin{array}{l}-0.352 \\
(0.80)\end{array}$ & $\begin{array}{l}0.462 \\
(1.48)\end{array}$ & $\begin{array}{l}0.898 \\
(1.32)\end{array}$ \\
\hline Female Headed Household Dummy & $\begin{array}{l}-0.212 \\
(0.03)\end{array}$ & $\begin{array}{l}-5.940 \\
(1.03)\end{array}$ & $\begin{array}{c}33.07 \\
(2.41)^{*}\end{array}$ \\
\hline Number of Local Cattle Owned & $\begin{array}{l}-1.523 \\
(1.88)\end{array}$ & $\begin{array}{c}5.527 \\
(9.53)^{* *}\end{array}$ & $\begin{array}{l}1.208 \\
(0.85)\end{array}$ \\
\hline Number of Improved Cattle Owned & $\begin{array}{c}16.40 \\
(6.47)^{* *}\end{array}$ & $\begin{array}{c}18.82 \\
(10.43)^{* *}\end{array}$ & $\begin{array}{l}3.010 \\
(0.71)\end{array}$ \\
\hline Constant & $\begin{array}{l}44.98 \\
(0.13)\end{array}$ & $\begin{array}{l}33.75 \\
(0.14)\end{array}$ & $\begin{array}{l}-1,683 \\
(2.39)^{*}\end{array}$ \\
\hline
\end{tabular}

Note: $*$ significant at $10 \%, * *$ significant at $5 \%$. 
Table 6. Determinants of Per Capita Income (Household Random Effects Model, USD)

\begin{tabular}{|c|c|c|c|}
\hline & Kenya & Uganda & Ethiopia \\
\hline & $(\mathrm{A})$ & (B) & $(\mathrm{C})$ \\
\hline \multicolumn{4}{|l|}{ Market Access to the Nearest Urban Center } \\
\hline \multirow[t]{2}{*}{ Total Distance $(\mathrm{km})$} & -0.765 & 0.364 & -0.082 \\
\hline & $(0.92)$ & $(1.02)$ & $(0.73)$ \\
\hline \multirow[t]{2}{*}{ Proportion of Loose Surface Road } & -105.1 & -99.03 & 51.54 \\
\hline & $(2.13)^{* *}$ & $(2.17)^{* *}$ & $(2.47)^{* *}$ \\
\hline \multirow[t]{2}{*}{ Proportion of Dirt Road } & -67.87 & -51.04 & n.a. \\
\hline & $(0.68)$ & $(1.96)^{* *}$ & \\
\hline \multicolumn{4}{|l|}{ Soil Fertility } \\
\hline \multirow[t]{2}{*}{ Carbon } & 22.24 & 7.810 & -24.43 \\
\hline & $(0.89)$ & $(0.76)$ & $(1.16)$ \\
\hline \multirow[t]{2}{*}{ Carbon Squared } & -1.650 & -1.246 & 3.936 \\
\hline & $(0.87)$ & $(1.10)$ & $(1.35)$ \\
\hline \multicolumn{4}{|l|}{ Household and Community Characteristics } \\
\hline \multicolumn{4}{|l|}{ Land Size (ha) } \\
\hline & 15.51 & 6.834 & 10.88 \\
\hline \multirow[t]{2}{*}{ Maximum Education Level of Male Adults } & $(1.83)^{* * *}$ & $(1.94)^{*}$ & $(3.77)^{* * *}$ \\
\hline & 5.456 & 7.892 & -0.046 \\
\hline \multirow[t]{2}{*}{ Maximum Education Level of Female Adults } & $(2.42)^{* * *}$ & $(3.47)^{* * *}$ & $(0.10)$ \\
\hline & 9.535 & 2.184 & 0.186 \\
\hline \multirow[t]{2}{*}{ Female Headed Household Dummy } & $(4.29)^{* * *}$ & $(0.87)$ & $(0.30)$ \\
\hline & -22.85 & -28.47 & 8.372 \\
\hline \multirow[t]{2}{*}{ Number of Local Cattle Owned } & $(1.01)$ & $(1.21)$ & $(0.71)$ \\
\hline & 14.03 & 7.298 & 4.065 \\
\hline \multirow[t]{2}{*}{ Number of Improved Cattle Owned } & $(3.33)^{* * *}$ & $(5.87)^{* * *}$ & $(3.48)^{* * *}$ \\
\hline & 32.38 & 12.69 & 34.90 \\
\hline \multirow[t]{2}{*}{ Constant } & $(8.45)^{* * *}$ & $(3.59)^{* * *}$ & $(9.60)^{* * *}$ \\
\hline & 139.2 & -36.14 & -309.0 \\
\hline Market Access to the Nearest Urban Center & $(0.20)$ & $(0.04)$ & $(0.60)$ \\
\hline
\end{tabular}

Note: * significant at $10 \%, * *$ significant at $5 \%, * * *$ significant at $1 \%$. 